\title{
Forage productivity and morphogenesis of Axonopus aureus under different nitrogen fertilization rates
}

\section{Newton de Lucena Costa ${ }^{1}$, Anibal de Moraes ${ }^{2}$, Alda Lúcia Gomes Monteiro ${ }^{3}$, Antonio Carlos Vargas Motta ${ }^{4}$, Ricardo Augusto de Oliveira ${ }^{2}$, Antonio Neri Azevedo Rodrigues ${ }^{5}$}

\author{
${ }^{1}$ Embrapa Roraima - Boa Vista, RR, Brazil. \\ 2 Departamento de Fitotecnia e Fitossanitarismo da UFPR - Curitiba, PR, Brazil. \\ ${ }^{3}$ Departamento de Zootecnia da UFPR - Curitiba, PR, Brazil. \\ ${ }^{4}$ Departamento de Solos da UFPR - Curitiba, PR, Brazil. \\ ${ }^{5}$ Instituto Federal de Rondônia - Colorado do Oeste, RO, Brazil.
}

\begin{abstract}
The effect of nitrogen (N) fertilization (0,50, 100 and $\left.200 \mathrm{~kg} \mathrm{~N}^{-1}\right)$ on forage yield and morphogenesis of Axonopus aureus was evaluated in the savannas of Roraima State, Brazil. The experimental design was in randomized blocks with three replicates. The grass showed high responsiveness to $\mathrm{N}$ fertilization. Dry weight (DW) yield, morphogenetic and structural traits and forage quality were positively affected by $\mathrm{N}$ fertilization. The effects of $\mathrm{N}$ fertilization on DW yield, $\mathrm{N}$ content, leaf appearance rate, leaf elongation rate, number of live leaves/tiller, final leaf length and leaf area index were quadratic and maximum values were estimated with application of $168.8\left(2,181 \mathrm{~kg} \mathrm{ha}^{-1}\right) ; 124.8(21.1 \mathrm{~g} / \mathrm{kg}) ; 158.5(0.163$ leaf $/$ day per tiller $)$; 172.3 (2.75 cm/tiller per day); $155.5(17.23 \mathrm{~cm}) ; 185.5\left(7.55\right.$ leaves/tiller) and $185.3(2.22) \mathrm{kg} \mathrm{N}$ ha $^{-1}$, respectively. Tiller population density and leaf senescence rate are directly proportional to increase in $\mathrm{N}$ rates, and the opposite occurs for $\mathrm{N}$ utilization efficiency and apparent $\mathrm{N}$ recovery.
\end{abstract}

Key Words: dry weight, leaf, senescence, tillering

\section{Introduction}

In Roraima State, Brazil, burning is a practice commonly utilized in the management of native pasture because of its low cost and easy application. Its main feature is the elimination of accumulated dry biomass which is not consumed by animals during the dry season, promoting an earlier, palatable and more nutritive regrowth, notably in periods of low forage availability (Gianluppi et al., 2001). Burning incorporates, in the form of ash, all the non-volatile nutrients of the biomass, which implicates increase in $\mathrm{pH}$ and soil fertility, and improved pasture growth. However, such high fertility is temporary, since about $97 \%$ of $\mathrm{N}, 61 \%$ of phosphorus (P), $76 \%$ of potassium $(\mathrm{K})$ and $65 \%$ of calcium $(\mathrm{Ca})$ and magnesium $(\mathrm{Mg})$ are transferred to the atmosphere and only 21 to $34 \%$ of $\mathrm{Mg}, \mathrm{Ca}, \mathrm{K}$ and $\mathrm{P}$ and $0.2 \%$ of $\mathrm{N}$ remain in the soil in the form of ash (Valencia \& Hernández, 2002). Nitrogen can be lost by leaching, volatilization or immobilization, a process in which the nutrients become unusable by the plant, so its deficiency is pointed as one of the main causes of low primary biological productivity of native pastures (Braga, 1998; Costa et al., 2011a).

Native pastures, formed almost exclusively by grasses, need a (chemical or biological) source for reposition of $\mathrm{N}$ so as to maintain their forage yield, and consequently prevent their degradation (Gianluppi et al., 2001; Costa et al., 2011b). Nitrogen is considered the main nutrient for maintenance of productivity and persistence of forage grasses; it constitutes the proteins that actively participate in the synthesis of organic compounds that make up the structure of the plant, in addition to maximizing the morphogenetic (leaf appearance, expansion and senescence rates) and structural (leaf size, tiller density and number of lives per tiller) characteristics of the grass. In soils deficient in N, plant growth and development become slow, tiller yield is negatively influenced and the protein content becomes inefficient to meet the requirements of the animal (Gomide, 1997).

In spite of being well adapted to the acid and lowfertility soils of the savanna, native grasses present low primary productivity; however, they seem to be responsible for improvement of the production environment, especially through fertilization. In the savannas of Venezuela, Barger et al. (2002) verified that $\mathrm{N}$ and $\mathrm{P}$ were the most limiting nutrients to forage productivity of Trachypogon plumosus. For Axonopus purpusii pastures, combined application of $\mathrm{N}$ $\left(100 \mathrm{~kg} \mathrm{~N} \mathrm{ha}^{-1}\right), \mathrm{P}\left(36 \mathrm{~kg} \mathrm{P}_{2} \mathrm{O}_{5} \mathrm{ha}^{-1}\right)$ and $\mathrm{K}\left(60 \mathrm{~kg} \mathrm{~K}_{2} \mathrm{O} \mathrm{ha}^{-1}\right)$ resulted in enhancement superior to $460 \%$ in its forage yield (554 vs. 3,108 kg DW ha ${ }^{-1}$ )(Sarmiento et al., 2006). Utilizing 
similar fertilization rates on pastures of Trachypogon plumosus + Trachypogon vestitus, Barger et al. (2002) observed increments of 71,17 and $126 \%$, respectively, for the application of $\mathrm{N}\left(7,180 \mathrm{~kg}^{\mathrm{DW}} \mathrm{ha}^{-1}\right), \mathrm{P}+\mathrm{K}\left(4,900 \mathrm{~kg} \mathrm{DW} \mathrm{ha}^{-1}\right)$ and $\mathrm{N}+\mathrm{P}+\mathrm{K}\left(9,490 \mathrm{~kg} \mathrm{DW} \mathrm{ha}^{-1}\right)$, in comparison with the control treatment $\left(4,200 \mathrm{~kg} \mathrm{DW} \mathrm{ha}^{-1}\right)$.

Among the many forage grasses that compose the native pastures of the savannas of Roraima, Axonopus aureus is one of the most important, accounting for about 30 to $40 \%$ of its botanical composition (Gianluppi et al., 2001). The grass presents perennial cycle, caespitous growth habit, plants of 40 to $60 \mathrm{~cm}$ in height and slightly hairy leaves. However, studies on the effects of improvement of production environment on the productive performance and alterations in their morphogenetic and structural characteristics for the proposal of more sustainable management practices are still scarce. In the present study, the effects of $\mathrm{N}$ fertilization on forage yield and morphogenetic and structural characteristics of Axonopus aureus in the savannas of Roraima were evaluated.

\section{Material and Methods}

The study was conducted in the Experimental Field of Embrapa Roraima, located in Boa Vista, Roraima State, Brazil, from May to September 2009, on a native pasture where Axonopus aureus represented $95 \%$ of its botanical composition. The soil of the experimental area is classified as a Yellow Oxisol (Xanthic Ferralsol) of medium texture, with the following chemical characteristics in the $0-20 \mathrm{~cm}$ layer: $\mathrm{pH}$ in water $=4.8 ; \mathrm{P}=1.8 \mathrm{mg} \mathrm{kg}^{-1} ; \mathrm{Ca}+\mathrm{Mg}=0.95 \mathrm{cmol}_{\mathrm{c}} \mathrm{dm}^{-3}$; $\mathrm{K}=0.01 \mathrm{cmol}_{\mathrm{c}} \mathrm{dm}^{-3} ; \mathrm{Al}=0.61 \mathrm{cmol}_{\mathrm{c}} \mathrm{dm}^{-3} ; \mathrm{H}+\mathrm{Al}=2.64 \mathrm{cmol}_{\mathrm{c}} \mathrm{dm}^{-3}$ and sum of bases $=0.91 \mathrm{cmol}_{\mathrm{c}} \cdot \mathrm{dm}^{-3}$; clay content $=232 \mathrm{~g} \mathrm{~kg}^{-1}$; and organic matter $=18.6 \mathrm{~g} \mathrm{~kg}^{-1}$. Precipitation and temperature during the experimental period were measured by a pluviometer and a thermometer installed in the experimental area (Table 1).

The experimental design was in randomized blocks with three replicates. Treatments consisted of four $\mathrm{N}$ rates $\left(0,50,100\right.$ and $\left.200 \mathrm{~kg} \mathrm{~N} \mathrm{ha}^{-1}\right)$, applied in the form of urea
$(44 \%$ of $\mathrm{N})$. The size of plots was of $2.0 \times 3.0 \mathrm{~m}$, with a useful area of $2.0 \mathrm{~m}^{2}$. The application of $\mathrm{N}$ was split in two times: half was given at pasture mowing, at the beginning of the experiment, and the other half, 45 days after. During the experimental period, three harvesting cuts were performed at 45-day intervals.

Dry weight (DW) yields were estimated through mechanical harvesting at a height of $5.0 \mathrm{~cm}$ above the ground. The material collected was weighed and left to dry in a forced-ventilation oven at $65^{\circ} \mathrm{C}$ for 72 hours. Absolute growth rate (AGR) was obtained by dividing the DW yield by the period of regrowth. The $\mathrm{N}$ utilization efficiency (NUE) was determined by relating the DW yield with the $\mathrm{N}$ rate applied. Nitrogen content was determined by the micro-Kjeldahl method. Apparent $\mathrm{N}$ recovery (ANR) was calculated by the formula:

ANR $=100 \times \mathrm{N}$ extracted by fertilized plants $-\mathrm{N}$ extracted by non-fertilized plants $\div \mathrm{N}$ rate applied.

The $\mathrm{N}$ critical level (NCL) was determined by methodology proposed by Lemaire \& Salette (1984), for $\mathrm{C}_{3}$ grasses, through the formula:

$\mathrm{NCL}=4.8 . \mathrm{DW}^{(-0.32)}$,

which estimates the $\mathrm{N}$ dilution curve as a function of DW accumulation. The $\mathrm{N}$ nutrition index (NNI) was determined as the ratio between $\mathrm{N}$ content in the DW and the NCL; it was considered satisfactory when the result equaled 1.0 (Lemaire \& Gastal, 1997).

To determine the morphogenetic and structural characteristics, four tussocks/plot were selected and three tillers/tussock were tagged, using plastic colored threads. Leaves were measured every three days, when the appearance, elongation and aging of leaves were computed. The leaf elongation rate (LER) and leaf appearance rate (LAR) were calculated by dividing the accumulated length of leaves and the total number of live leaves on the tiller (NLLT), respectively, by the period of regrowth. The final leaf length (FLL) was determined by dividing the total tiller elongation by its number of leaves. For the calculation of leaf area, at each regrowth age, samples were collected from fully expanded green leaves, aiming

Table 1 - Precipitation, minimum, maximum and mean temperatures and solar radiation recorded during the experimental period

\begin{tabular}{|c|c|c|c|c|c|}
\hline \multirow{2}{*}{ Months } & \multirow{2}{*}{ Precipitation (mm) } & \multicolumn{3}{|c|}{ Temperature $\left({ }^{\circ} \mathrm{C}\right)$} & \multirow{2}{*}{ Solar radiation $\mathrm{MJ} / \mathrm{m}^{2}$} \\
\hline & & Minimum & Maximum & Mean & \\
\hline May & $298.1(163.2)$ & $24.3(23.4)$ & $32.4(31.1)$ & $28.4(27.3)$ & $397.4(414.2)$ \\
\hline June & $259.2(229.0)$ & $23.8(22.8)$ & $33.2(30.6)$ & $28.5(26.7)$ & $401.1(387.5)$ \\
\hline July & $311.0(268.6)$ & $22.1(22.5)$ & $31.7(30.5)$ & $26.9(26.9)$ & $432.5(422.7)$ \\
\hline August & $185.8(207.9)$ & $20.0(23.0)$ & $31.2(31.6)$ & $26.6(27.3)$ & $459.2(441.1)$ \\
\hline September & $120.0(80.1)$ & $24.7(23.7)$ & $32.3(33.2)$ & $28.5(28.4)$ & $467.1(458.2)$ \\
\hline
\end{tabular}

Values in parenthesis represent the historical average of the 1990-2011 period.

Source: Meteorological Station of Embrapa Roraima. 
to obtain an area between 200 and $300 \mathrm{~cm}^{2}$, estimated with the aid of an optical electronic planimeter (Li-Cor, model LI -3100C). Subsequently, the samples were taken to a forced-ventilation oven at $65{ }^{\circ} \mathrm{C}$ until they reached constant weight, so the leaf DW was calculated. Specific leaf area (SLA) was determined as the ratio between the area of green leaves and their DW $\left(\mathrm{m}^{2} \mathrm{~g}^{-1}\right)$. Leaf area index (LAI) was determined as the product between the total DW of green leaves $\left(\mathrm{g} \mathrm{m}^{-2}\right)$ by SLA $\left(\mathrm{m}^{2} \mathrm{~g}^{-1}\right)$. Leaf senescence rate (LSR) was obtained by dividing the length of the leaves that presented yellow staining or necrosis by age at regrowth. Tiller population density (TPD) was estimated with the use of $0.25 \mathrm{~m}^{2}$ metal frames $(50 \times 50 \mathrm{~cm})$, divided in four points at random in each plot; every tiller, in each regrowth age, was computed.

The data were subjected to analysis of variance (ANOVA), $F$ test, and regression considering the significance level of $5 \%$ of probability. To estimate the response of the parameters evaluated as a function of the nitrogen levels, the choice of regression models was based on the significance of the linear and quadratic coefficients through the test at the level $5 \%$ of probability.

\section{Results and Discussion}

The DW yield and AGR were influenced $(\mathrm{P}<0.05)$ by $\mathrm{N}$ fertilization; the rate of maximum technical efficiency was estimated at $168.8\left(2,181 \mathrm{~kg} \mathrm{DW} \mathrm{ha}^{-1}\right.$ and $14.3 \mathrm{~kg}$ DW ha $^{-1}$ day $^{-1}$, respectively) (Figures 1 and 2). Rippstein et al. (2001), with Trachypogon vestitus, native grass of savannas from Colombia, and Cunha et al. (2001), in native pastures of Rio Grande do Sul State, verified linear effects of N fertilization on the forage yields with application of up to 150 and $200 \mathrm{~kg} \mathrm{~N}^{-1} \mathrm{year}^{-1}$, respectively. Scheffer-Basso et al. (2010), in a Paspalum pauciciliatum pasture, observed that application of $50 \mathrm{~kg} \mathrm{~N} \mathrm{ha}^{-1}$ resulted in an increase above $250 \%$ in the forage yield of the grass $(3,523 v s .1,022 \mathrm{~kg}$ DW ha ${ }^{-1}$ ), whereas Siewerdt et al. (1995), for native pastures with predominance of Paspalum notatum, $P$. distichum, $P$. modestum and Axonopus compressus, estimated maximum yield with application of $453 \mathrm{~kg} \mathrm{~N} \mathrm{ha}^{-1}\left(10,133 \mathrm{~kg} \mathrm{DW} \mathrm{ha}^{-1}\right)$. Costa et al. (2011b), in non-fertilized A. aureus pastures subjected to different rest periods, verified yield of $721 ; 976$; and 1,345 kg DW ha ${ }^{-1}$ for 35, 49 and 63 days, respectively, which were inferior to the values recorded in this study. Reducing the maintenance respiration and stimulating this growth - directly proportional to the protein content of the plant and responsible for the yield of new organic compounds - nitrogen contributes positively to the greater accumulation of biomass (Gastal et al., 2010). A nitrogen content in the leaves inferior to $3 \%$ reduces the capacity of carbon (C) fixation, and consequently, the primary biological productivity of the grass (Jeuffroy et al., 2002).

Nitrogen content responded quadratically to $\mathrm{N}$ rates $\left(\hat{y}=17.95+0.0499 * x-0.0002 * x^{2} ; R^{2}=0.87\right)$ and the maximum value was obtained with application of $124.8 \mathrm{~kg}$ $\mathrm{N} \mathrm{ha}^{-1}\left(21.1 \mathrm{~g} \mathrm{~kg}^{-1}\right)$ (Table 2). Considering that $\mathrm{N}$ contents below $11.2 \mathrm{~g} \mathrm{~kg}^{-1}$ are limiting to animal growth, for implying lower voluntary intake, reduction in forage digestibility and negative $\mathrm{N}$ balance, the grass would satisfactorily supply the minimum requirements of ruminants, regardless of $\mathrm{N}$ fertilization rate (Lemaire, 1997). The ratio between DW and $\mathrm{N}$ content was fitted to the exponential regression model $\left(\hat{y}=10.949 \cdot \mathrm{e}^{\left(-0.25^{*} \mathrm{x}\right)}-\mathrm{R}^{2}=0.84\right)$, demonstrating the effect of dilution of its contents, as a function of the greater DW accumulation with increase in the levels of $\mathrm{N}$ fertilization. According to Gastal \& Lemaire (2002), this behavior is a result of the greater proportion of structural material

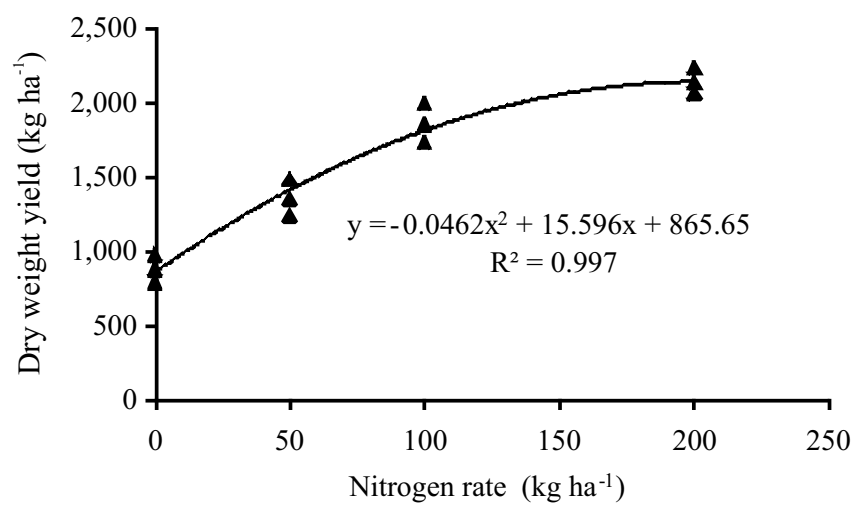

Figure 1 - Dry weight yield of Axonopus aureus according to N fertilization rates.

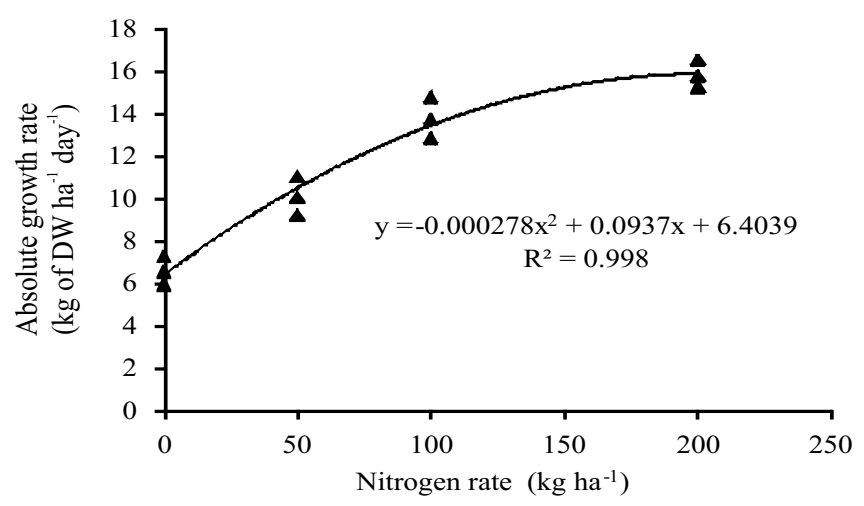

Figure 2 - Absolute growth rate of Axonopus aureus according to $\mathrm{N}$ fertilization rates. 
and reserves with plant growth, which contain little $\mathrm{N}$, in addition to the non-uniformity of the $\mathrm{N}$ distribution between leaves according to the solar radiation received within the canopy. The $\mathrm{N}$ contents, for all $\mathrm{N}$ rates, were below the critical level proposed by Lemaire \& Salette (1984), which implies insufficient NNI to supply the N requirement of the grass; therefore, the ratio between the $\mathrm{N}$ content in the $\mathrm{DW}$ and NNI was below 1.0.

Nitrogen use efficiency and apparent nitrogen recovery were inversely proportional to the rates utilized (Table 2). Similar trends were verified by Siewerdt et al. (1995) for Paspalum spp. pastures $(28.8,21.7$ and $17.1 \mathrm{~kg} \mathrm{DW} / \mathrm{kg} \mathrm{N}$ and 45.6, 41.2 and $36.8 \%$ for 100, 200 and $300 \mathrm{~kg} \mathrm{~N} \mathrm{ha}^{-1}$, respectively). Assessing the effects of $\mathrm{N}$ fertilization ( 0 , 60, 180 and $360 \mathrm{~kg} \mathrm{~N} \mathrm{ha}^{-1}$ year $^{-1}$ ) in Paspalum notatum cv. André da Rocha, Townsend (2008) observed maximum forage yield with application of $239 \mathrm{~kg} \mathrm{~N} \mathrm{ha}^{-1}$; however, the greatest NUE rates were reached under fertilization levels between 80 and $160 \mathrm{~N} \mathrm{ha}^{-1}$ year $^{-1}$. Primavesi et al. (2004) verified that the ANR of Cynodon dactylon cv. Coastcross was inversely proportional to $\mathrm{N}$ rates, but the highest values were achieved with the utilization of ammonium nitrate $(75,68$ and $45 \%)$, in comparison with urea $(52,46$ and $37 \%$ ) for 50,100 and $200 \mathrm{~kg} \mathrm{~N} \mathrm{ha}^{-1}$, respectively.

The ratio between $\mathrm{N}$ fertilization and NLLT was fitted to the quadratic regression model and the maximum value was obtained with application of $185.5 \mathrm{~kg} \mathrm{~N} \mathrm{ha}^{-1}$ (7.55 leaves tiller ${ }^{-1}$ ) (Figure 3). The values achieved were superior to those reported by Costa et al. (2011b) for $A$. aureus pastures under different grazing intensities (4.8, 5.3 and 6.1 leaves tiller ${ }^{-1}$ at 35, 49 and 56 days of regrowth, respectively). For Garcez Neto et al. (2002), the main effect of $\mathrm{N}$ on the NLLT would be the increase in leaf lifespan. The action of $\mathrm{N}$ would be associated with the maintenance of greater photosynthetic capacity for longer periods, with no significant internal reallocation of the $\mathrm{N}$ from older leaves. However, Patês et al. (2007) verified that the NLLT of Panicum maximum cv. Tanzania was inversely proportional to the $\mathrm{N}$ rates applied $(0,15,33$ and $50 \mathrm{mg} \mathrm{N} / \mathrm{kg}$ soil), as a consequence of the prioritization of the production of a higher number of tillers over leaves tiller-1.
The effects of $\mathrm{N}$ fertilization on LAR, LER and FLL were quadratic, and the maximum values were achieved with the application of 158.5 ( 0.163 leaves/day tiller $\left.{ }^{-1}\right)$, $172.3\left(2.75 \mathrm{~cm} /\right.$ tiller day $\left.^{-1}\right)$ and $155.5 \mathrm{~kg} \mathrm{~N} \mathrm{ha}^{-1}(17.23 \mathrm{~cm})$ (Figures 4, 5 and 6), respectively. Under limiting nutritional conditions, the strategy for maintenance of growth would be sparing assimilates, started by the commitment of the tillering, going trough reduction in FLL and leaf lifespan (Nabinger \& Pontes, 2001). The correlations between DW yield and LAR $(r=0.94 ; P=0.0021)$ and $L E R(r=0.91$; $\mathrm{P}=0.0042$ ) were positive and significant. The LAR, LER and FLL obtained in this study were superior to those reported by Costa et al. (2011b) for non-fertilized pastures of A. aureus, during the rainy period, who estimated 0.141 leaves/tiller day ${ }^{-1}, 1.54 \mathrm{~cm} /$ tiller day ${ }^{-1}$ and $13.7 \mathrm{~cm}$, for plants at 49 days of regrowth. Leaf elongation rate explained $90 \%$ the increase in the DW yield of the grass, according to the $\mathrm{N}$ fertilization. Likewise, Petry et al. (2005) verified quadratic effect of $\mathrm{N}$ fertilization $(0,50,100,150$ and $200 \mathrm{mg} \mathrm{N} / \mathrm{kg}$ soil) on LAR, LER and FLL of P. maximum cv. Mombasa, estimating maximum values with application of 73, 121 and $103 \mathrm{mg} \mathrm{N} / \mathrm{kg}$ soil, respectively. On pastures of Andropogon lateralis, a native grass of the South of Brazil, Bandinelli et al. (2003) estimated highest LAR and LER with the application of $100 \mathrm{~kg} \mathrm{~N} \mathrm{ha}^{-1}(0.085$ leaves/day tiller ${ }^{-1}$ and $0.66 \mathrm{~cm} /$ day tiller $\left.{ }^{-1}\right)$, in comparison

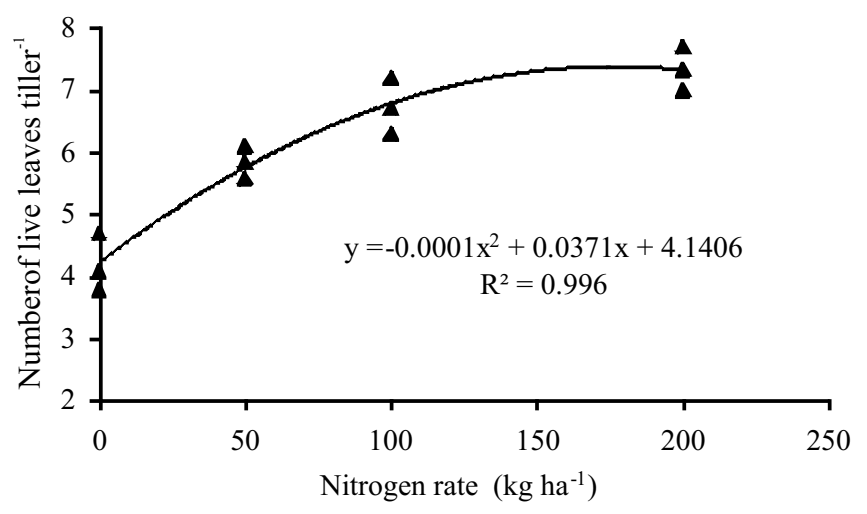

Figure 3 - Number of live leaves/tiller of Axonopus aureus according to $\mathrm{N}$ fertilization rates.

Table 2 - Nitrogen data in Axonopus aureus according to $\mathrm{N}$ fertilization rates

\begin{tabular}{|c|c|c|c|c|c|}
\hline Nitrogen rates $\left(\mathrm{kg} \mathrm{ha}^{-1}\right)$ & $\mathrm{N}$ content $\left(\mathrm{g} \mathrm{kg}^{-1}\right)$ & $\operatorname{NCL}\left(\mathrm{g} \mathrm{kg}^{-1}\right)$ & NNI (N/NCL content) & NUE (kg DW/kg N) & NAR (\%) \\
\hline 0 & $18.2 \mathrm{c}$ & 50.3 & 0.36 & - & - \\
\hline 50 & $19.3 b$ & 42.2 & 0.46 & $29.8 \mathrm{a}$ & $28.1 \mathrm{a}$ \\
\hline 100 & $21.5 \mathrm{a}$ & 38.5 & 0.56 & $19.9 b$ & $24.5 \mathrm{a}$ \\
\hline 200 & $20.1 \mathrm{ab}$ & 37.7 & 0.53 & $10.7 \mathrm{c}$ & $13.3 b$ \\
\hline
\end{tabular}

Means followed by the same letter are not different $(\mathrm{P}>0.05)$ by the Tukey test.

$\mathrm{NCL}$ - nitrogen critical level (criticalN $=4.8 . \mathrm{DW}\left({ }^{-0.32}\right)$ ); NNI - nitrogen nutrition index; NUE - nitrogen use efficiency; NAR - nitrogen apparent recovery. DW - dry weight. 


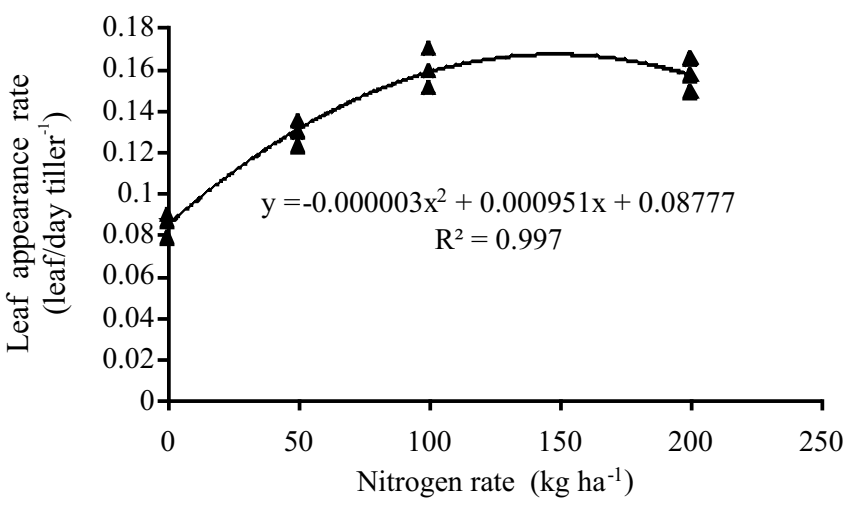

Figure 4 - Leaf appearance rate of Axonopus aureus according to $\mathrm{N}$ fertilization rates.

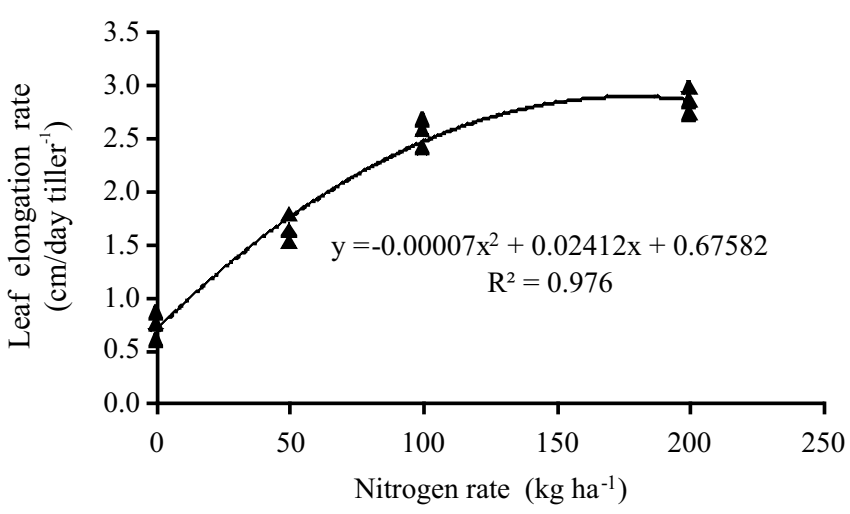

Figure 5 - Leaf elongation rate of Axonopus aureus according to $\mathrm{N}$ fertilization rates.

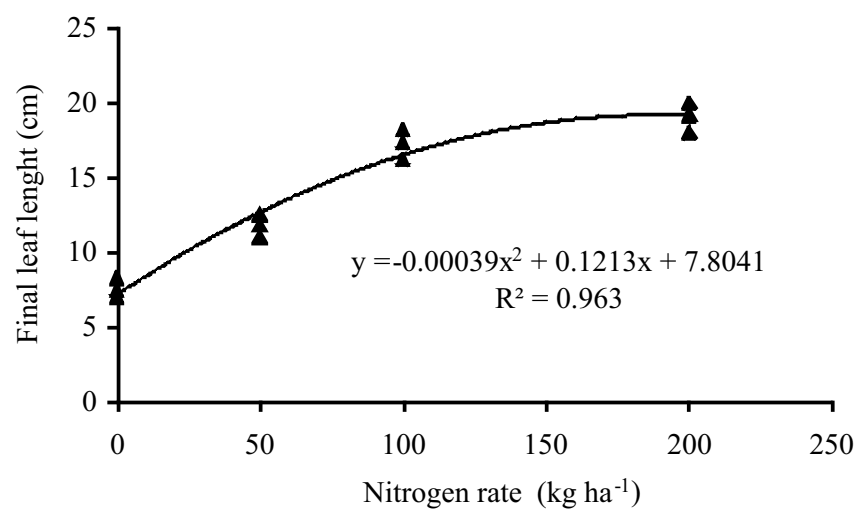

Figure 6 - Final leaf length of Axonopus aureus according to $\mathrm{N}$ fertilization rates. with the control treatment ( 0.065 leaves/day tiller ${ }^{-1}$ and $0.47 \mathrm{~cm} /$ day tiller ${ }^{-1}$ ) or the application of $200 \mathrm{~kg} \mathrm{~N} \mathrm{ha}^{-1}$ ( 0.076 leaves $/$ day tiller ${ }^{-1}$ and $0.63 \mathrm{~cm} /$ day tiller $\left.^{-1}\right)$.

The role of $\mathrm{N}$ supply on the LAR can be analyzed as a result of the simultaneous combination of several factors, such as sheath height, leaf elongation and temperature. The rate at which leafs elongate alters the leaf blade appearance pattern, according to the change in the time taken by the leaf from its start in the meristem to its appearance above the pseudostem formed by the older leaves (Duru \& Ducrocq, 2000). For Garcez Neto et al. (2002), when responding to the $\mathrm{N}$ supply, LER would be the main agent to modify LAR. Successful leaves appearing at close insertion intervals, but under elevated elongation rates, supported by the additional $\mathrm{N}$ supply, would establish higher LAR.

In grasses, leaf elongation is restricted to an area at the base of the leaf undergoing expansion protected by the pseudostem: active local of high nutrient requirement, where $\mathrm{N}$ acts as the main responsible for the cell division and expansion. According to Alexandrino et al. (2011), LAR and LER have a negative relationship, which indicates that the greater the LAR, the shorter the time available for elongation. In this study, the relationship between these two variables was positive and significant $(r=0.97 ; \mathrm{P}<0.01)$, possibly, as a consequence of the utilization of favorable environmental conditions, which enabled plants to express their maximum growth potential. Grant et al. (1981), in annual ryegrass (Lolium perenne L.), observed that LER was positively correlated with the amount of green leaves remaining on the tiller after defoliation, and the size of the tiller is the main responsible for the period of leaf expansion.

Leaf area index responded to $\mathrm{N}$ fertilization quadratically and the maximum value was recorded with application of $185.3 \mathrm{~kg} \mathrm{~N} \mathrm{ha}^{-1}$ (2.22) (Figure 7). Since LAI represents the synthesis of the morphogenetic and structural grass characteristics, it reflects the balance of the processes which determine the supply (photosynthesis) and the demand (respiration, accumulation of reserves, synthesis and senescence of tissues) of photoassimilates, which set the growth of the pasture (Nabinger \& Pontes, 2001). When nitrogen modifies the structure and morphological composition of the pasture, resulting from the greater number of live leaves per tiller, it promotes increase in the leaf appearance and elongation rates, with positive reflection in their final length, resulting in greater LAI and, thus, efficiency at light absorption and photosynthetic capacity of the sward (Lemaire, 1997). The values recorded were superior to those reported by Costa et al. (2011b) for non-fertilized $A$. aureus pastures under different harvest 
frequencies (10.6, 13.4 and $14.9 \mathrm{~cm}^{2}$ tiller ${ }^{-1}$ for 28,35 and 42 days of regrowth, respectively).

Nitrogen fertilization affected TPD positively and linearly $(\mathrm{P}<0.05$; Figure 8$)$. The correlation between DW yield and TPD was positive and significant $(\mathrm{r}=0.99 ; \mathrm{P}=0.0032)$, explaining $90 \%$ the increase verified in the grass forage yields according to $\mathrm{N}$ fertilization rates. Positive effects of $\mathrm{N}$ fertilization on the TPD of $P$. maximum cvs. Tanzânia and Mombasa, regardless of phosphorus fertilization, were reported by Patês et al. (2007) and Garcez Neto et al. (2002), respectively. According to Alexandrino et al. (2010), $\mathrm{N}$ intensively interferes with the activation of meristematic tissues (axillary buds); its deficit increases the number of dormant buds, whereas the adequate supply enables maximum grass tillering. For Garcez Neto et al. (2002), tillering is a structural characteristic heavily affected by nutritional, environmental and management factors, which define the morphogenetic characteristics that, in turn, are crucial for the morphogenetic response of forage plants. Yield of new tillers is usually a continuous process accelerated by plant defoliation as a consequence of the improvement of the light environment at the base of the sward (higher red:far-red radiations ratio), controlled by two main factors: supply of energy for the photosynthesis and number and activity of growth spots (Gastal \& Lemaire, 2002). Since individual tillers have a limited and variable lifespan, as a result of biotic and abiotic factors, their population can be maintained by a continuous replacement of dead tillers; this mechanism is the key point to grass perenniality.

Leaf senescence rate was affected positively and linearly by $\mathrm{N}$ fertilization (Figure 9). Bandinelli et al. (2003) verified that LSR of $A$. lateralis were directly proportional to $\mathrm{N}$ rates $\left(0.169,0.194\right.$ and $0.197 \mathrm{~cm} /$ day tiller ${ }^{-1}$ for 0 , 100 and $200 \mathrm{~kg} \mathrm{~N} \mathrm{ha}^{-1}$, respectively). In the absence of fertilization, plants remained longer with their leaves alive rather than having new leaves, i.e., the senescence process was accelerated with increase in $\mathrm{N}$ rates, reducing leaf lifespan, as a consequence of the greater tissue renewal in plants (Gastal et al., 2010). The values recorded were lower than those reported by Costa et al. (2011b), who estimated a LSR of $0.224 \mathrm{~cm} /$ day tiller ${ }^{-1}$ for $A$. aureus plants at 45 days of regrowth, during the rainy period. Senescence is a natural process that characterizes the last developmental period of a leaf started after its complete expansion, whose intensity progressively becomes more pronounced with increase in leaf area, as a consequence of the shading of upper leaves over those at the lower portion of the stem, which have their photosynthetic capacity reduced (Gastal et al., 2010). Despite the negative effect

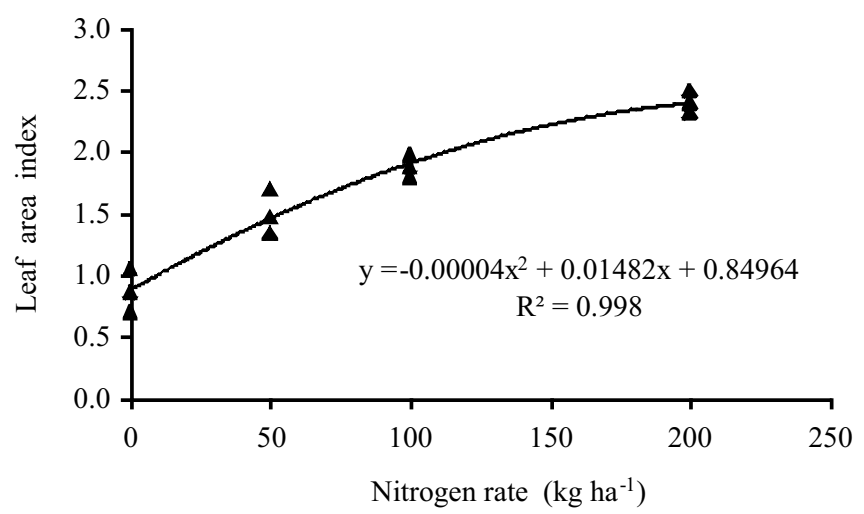

Figure 7 - Leaf area index of Axonopus aureus according to $\mathrm{N}$ fertilization rates.

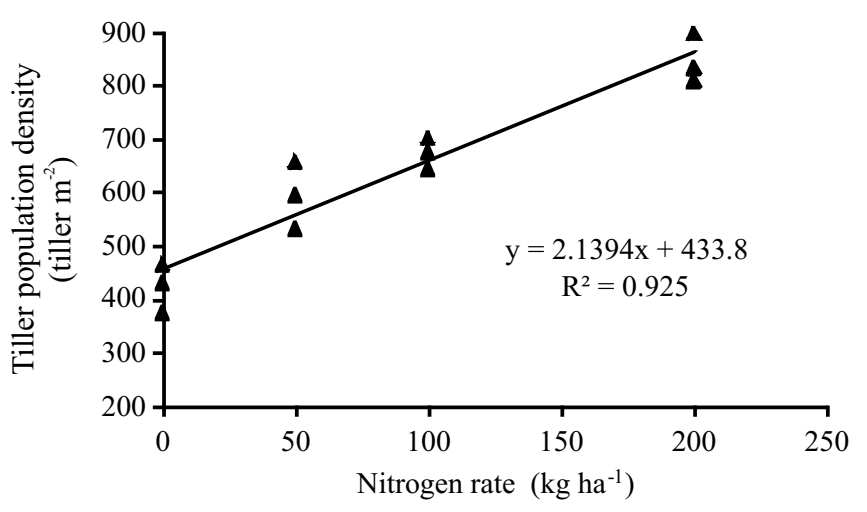

Figure 8 - Tiller population density of Axonopus aureus according to $\mathrm{N}$ fertilization rates.

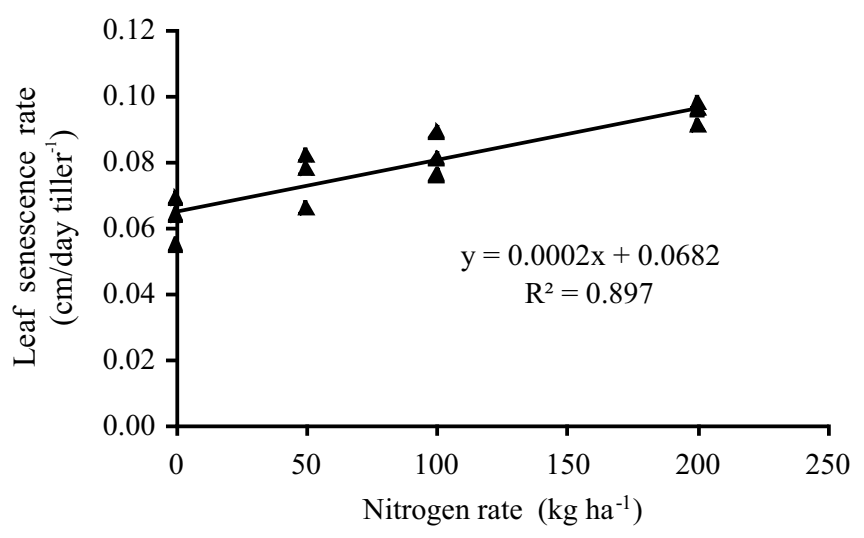

Figure 9 - Leaf senescence rate of Axonopus aureus according to $\mathrm{N}$ fertilization rates. 
on the quality of the forage, senescence represents an important physiological process in the grass tissues flow, since about $50 \%$ of $\mathrm{C}$ and $80 \%$ of $\mathrm{N}$ can be recycled from senescent leaves and utilized for the yield of new leaf tissues (Carrère et al., 1997; Lemaire \& Agnusdei, 2000; Alexandrino et al., 2011). In T. plumosus pastures, Medina (1982) verified internal retranslocation of $64 \%$ of the $N$ of senescent leaves to those undergoing expansion, whereas Silva \& Haridasan (2007), with several native grasses of the savanna, estimated retranslocation efficiency of 34.9, $68.4,86.9$ and $42.2 \%$ for $\mathrm{N}, \mathrm{P}, \mathrm{K}$ and $\mathrm{Mg}$, respectively.

\section{Conclusions}

Nitrogen fertilization affects forage yield, absolute growth rate, nitrogen content and morphogenetic and structural characteristics of Axonopus aureus. During the rainy season, the grass responds positively to nitrogen fertilization until the rate of $169 \mathrm{~kg} \mathrm{~N} \mathrm{ha}^{-1}$. Grass senescence process is accelerated by nitrogen fertilization. Nitrogen use efficiency and apparent nitrogen recovery are inversely proportional to nitrogen rates.

\section{References}

ALEXANDRINO, E.; CÂNDIDO, M.J.D.; GOMIDE, J.A. Fluxo de biomassa e taxa de acúmulo de forragem em capim Mombaça mantido sob diferentes alturas. Revista Brasileira de Saúde e Produção Animal, v.12, n.1, p.59-71, 2011.

ALEXANDRINO, E.; VAZ, R.G.M.; SANTOS, A.C. Características da Brachiaria brizantha cv. Marandu durante o seu estabelecimento submetida a diferentes doses de nitrogênio. Bioscience Journal, v.26, n.6, p.886-893, 2010.

BANDINELLI, D.G.; QUADROS, F.L.F.; GONÇALVES, E.N. et al. Variáveis morfogênicas de Andropogon lateralis Nees submetido a níveis de nitrogênio nas quatro estações do ano. Ciência Rural, v.33, n.1, p.71-76, 2003.

BARGER, N.N.; D'ANTONIO, C.M.; GHNEIM, T. et al. Nutrient limitation to primary productivity in a secondary savanna in Venezuela. Biotropica, v.34, n.4, p.493-501, 2002.

BRAGA, R.M. A agropecuária em Roraima: considerações históricas, de produção e geração de conhecimento. Boa Vista: Embrapa Roraima, 1998. 63p. (Documentos, 1).

CARRÈRE, P.; LOUAULT, F.; SOUSSANA, J.F. Tissue turnover within grass-clover mixed swards grazed by sheep. Methodology for calculating growth, senescence and intake fluxes. Journal of Applied Ecology, v.34, p.333-348, 1997.

COSTA, N.L.; GIANLUPPI, V.; MORAES, A. Produtividade de forragem e morfogênese de Trachypogon vestitus em diferentes idades de rebrota nos cerrados de Roraima. Revista Brasileira de Saúde e Produção Animal, v.12, n.42, p.935-948, 2011a.

COSTA, N.L.; GIANLUPPI, V.; MORAES, A. et al. Produtividade de forragem e características morfogênicas e estruturais de Axonopus aureus nos cerrados de Roraima. Amazônia Ciência \& Desenvolvimento, v.6, n.12, p.7-22, 2011b.

CUNHA, M.K.; SIEWERDT, L.; SILVEIRA JÚNIOR, P. et al. Doses de nitrogênio e enxofre na produção e qualidade da forragem de campo natural de Planossolo no Rio Grande do Sul. Revista Brasileira de Zootecnia, v.30, n.3, p.651-658, 2001.
DURU, M.; DUCROCQ, H. Growth and senescence of the successive leaves on a Cocksfoot tiller. Effect of nitrogen and cutting regime. Annals of Botany, v.85, p.64S-6S3, 2000.

GARCEZ NETO, A.F.; NASCIMENTO JÚNIOR, D.; REGAZZI, A.J. et al. Respostas morfogênicas e estruturais de Panicum maximum cv. Mombaça sob diferentes níveis de adubação nitrogenada e alturas de corte. Revista Brasileira de Zootecnia, v.31, n.5, p.1890-1900, 2002.

GASTAL, F.; DAWSON, L.A.; THORNTON, B. Responses of plant traits of four grasses from constrating habitats to defoliation and $\mathrm{N}$ supply. Nutrient Cycling in Agroecosystems, v.88, p.245-258, 2010.

GASTAL, F.; LEMAIRE, G. $\mathrm{N}$ uptake and distribution in crops: an agronomical and ecophysiological perspective. Journal of Experimental Botany, v.53, n.370, p.789-799, 2002.

GIANLUPPI, D.; GIANLUPPI, V.; SMIDERLE, O. Produção de pastagens no cerrado de Roraima. Boa Vista: Embrapa Roraima, 2001. 4p. (Comunicado Técnico, 14).

GOMIDE, J.A. Morfogênese e análise de crescimento de gramíneas tropicais. In: SIMPÓSIO INTERNACIONAL SOBRE PRODUÇÃO ANIMAL EM PASTEJO, 1997, Viçosa, MG. Anais... Viçosa, MG: UFV, 1997. p.411-430.

GRANT, S.A.; BERTHARM, G.T.; TORVELL, L. Components of regrowth in grazed and cut Lolium perenne swards. Grass and Forage Science, v.36, p.155-168, 1981.

JEUFFROY, M.H.; NEY, B.; OURRY, A. Integrated physiological and agronomic modelling of $\mathrm{N}$ capture and use within the plant. Journal of Experimental Botany, v.53, n.370, p.809-823, 2002.

LEMAIRE, G. The physiology of grass growth under grazing: tissue turnover. In: SIMPÓSIO INTERNACIONAL SOBRE PRODUÇÃO ANIMAL EM PASTEJO, 1997, Viçosa, MG. Anais... Viçosa, MG: UFV, 1997. p.117-144.

LEMAIRE, G.; AGNUSDEI, M. Leaf tissue turnover and efficiency of herbage utilization. In: LEMAIRE, G.; HODGSON, J.; MORAES, A. et al. (Eds). Grassland ecophysiology and grazing ecology. London: CAB International, 2000. p.265-288.

LEMAIRE, G.; GASTAL, F. N uptake and distribuition in plant canopies. In: LEMAIRE, G. (Ed.). Diagnosis of nitrogen status in crops. Heidelberg: Springer-Verlag, 1997. p.3-43.

LEMAIRE, G; SALETTE, J. Relation entre dynamique de croissance et dymamique de prélèvement d'azote pour un peuplement de graminées fourragères. 1. Etude de l'effet du milieu. Agronomie, v.4, p.223-230, 1984.

MEDINA, E. Nitrogen balance in Trachypogon grasslands of central Venezuela. Plant and Soil, v.67, p.305-314, 1982.

NABINGER, C.; PONTES, L.S. Morfogênese de plantas forrageiras e estrutura do pasto. In: REUNIÃO ANUAL DA SOCIEDADE BRASILEIRA DE ZOOTECNIA, 38., 2001, Piracicaba. Anais... Piracicaba: SBZ, 2001. p.755-771.

PATÊS, N.M.S.; PIRES, A.J.V.; SILVA, C.C.F. et al. Características morfogênicas e estruturais do capim-tanzânia submetido a doses de fósforo e nitrogênio. Revista Brasileira de Zootecnia, v.36, n.6, p.1736-1741, 2007.

PETRY, L.; MESQUITA, E.E.; NERES, M.A. et al. Morfogênese de Panicum maximum cultivares Mombaça, Tanzânia e Millenium sob doses de nitrogênio. In: REUNIÃO ANUAL DA SOCIEDADE BRASILEIRA DE ZOOTECNIA, 42., 2005, Goiânia. Anais... Goiânia: SBZ, 2005. 3p. (CD-ROM).

PRIMAVESI, A.C.; PRIMAVESI, O.; CORRÊA, L.A. et al. Adubação nitrogenada em capim-Coastcross: Efeitos na extração de nutrientes e recuperação aparente do nitrogênio. Revista Brasileira de Zootecnia, v.33, n.1, p.68-78, 2004.

RIPPSTEIN, G.; ESCOBAR, G.; MOTTA, F. Agroecologia y biodiversidad de los Llanos Orientales de Colombia. Cali, Colombia: CIAT, 2001. 302p.

SARMIENTO, G.; SILVA, M.P.; NARANJO, M.E. et al. Nitrogen and phosphorus as limiting factors for growth and primary 
production in a flooded savanna in the Venezuelan Llanos. Journal of Tropical Ecology, v.22, p.203-212, 2006.

SCHEFFER-BASSO, S.M.; FÁVERO, F.; CESARO, E.P. et al. Preliminary evaluation of Paspalum pauciciliatum: seasonal production and nitrogen response. ARS Veterinaria, v.26, n.1, p.53-59, 2010.

SIEWERDT, L.; NUNES, A.P.; SILVEIRA JÚNIOR, P. Efeito da adubação nitrogenada na produção e qualidade da matéria seca de um campo natural de Planossolo no Rio Grande do Sul. Revista Brasileira de Agrociência, v.1, n.3, p.157-162, 1995.
SILVA, J.S.O.; HARIDASAN, M. Acúmulo de biomassa aérea e concentração de nutrientes em Melinis minutiflora P. Beauv. e gramíneas nativas do cerrado. Revista Brasileira de Botânica, v.30, n.2, p.337-344, 2007

TOWNSEND, C.R. Características produtivas de gramíneas nativas do gênero Paspalum, em resposta à disponibilidade de nitrogênio. 2008. 254f. Tese (Doutorado em Zootecnia) Universidade Federal do Rio Grande do Sul, Porto Alegre.

VALENCIA, H.; HERNÁNDEZ, L. The losses of nutrients by fire in a savanna vegetation of Trachypogon. Revista de Biologia Tropical, v.50, n.3-4, p.1013-1019, 2002. 